\title{
Survival and mortality of
} grasshopper egg pods in semi-arid cereal cropping areas of northern Benin

\author{
Journal Article \\ Author(s): \\ Shah, P.A.; Godonou, I.; Gbongboui, C.; Hossou, A.; Lomer, C.J. \\ Publication date: \\ 1998 \\ Permanent link: \\ https://doi.org/10.3929/ethz-b-000422576
}

Rights / license:

In Copyright - Non-Commercial Use Permitted

Originally published in:

Bulletin of Entomological Research 88(4), https://doi.org/10.1017/S000748530004219X 


\title{
Survival and mortality of grasshopper egg pods in semi-arid cereal cropping areas of northern Benin
}

\author{
P.A. Shah ${ }^{1,2 *}$, I. Godonou ${ }^{2}$, C. Gbongboui ${ }^{2}$, A. Hossou ${ }^{3}$ \\ and C.J. Lomer ${ }^{2}$ \\ 'Institute of Microbiology, Swiss Federal Institute of Technology, \\ LFV E14, ETH- Zentrum, CH-8092 Zurich, Switzerland: ' International \\ Institute of Tropical Agriculture, Plant Health Management Division, \\ Cotonou, BP 08-0932, Republic of Benin: ${ }^{3}$ Service Protection des
} Végétaux, Porto Novo, BP 58, Republic of Benin

\begin{abstract}
Surveys of egg pods of agriculturally important grasshoppers were carried out in northern Benin between 1992 and 1995. Searches were made of oviposition sites under shrubs of the perennial legume Piliostigma thonningi along field margins. In 1993 and 1995, surveys were extended to include sorghum, Sorghum bicolor, and the perennial thatch grass Vetiveria nigritana. The four principal grasshopper species found at these oviposition sites were Hieroglyphus daganensis Krauss, Cataloipus fuscocoeruleipes Sjöstedt, Kraussaria angulifera (Krauss) and Tylotropidius gracilipes Brancsik comprising $86 \%$ of 4545 identified egg pods while 651 egg pods could not be identified to species level. Predation by meloid beetles (Epicauta, Mylabris and Psalydolytta spp.) varied between 0 and $50 \%$ for the four dominant grasshopper species. From 1993 and 1994 data, nymphal eclosion from egg pods damaged by meloids was significantly lower than emergence from undamaged egg pods. The hymenopterous parasitoids Scelio africanus Risbec and S. mauriticanus Risbec were reared from the four dominant grasshopper species and parasitism levels of $0.0-3.3 \%$ were recorded from these hosts. There were significant differences in nymphal emergences between parasitized and unparasitized egg pods of H. daganensis.
\end{abstract}

\section{Introduction}

Orthoptera generally oviposit in the upper soil layers producing egg masses which may or may not be enclosed by i protective wall. In the latter case, secretions from female accessory glands adhere to soil particles forming a capsule of zemented soil around the oothecae or egg cases (Uvarov, 1977; Greathead, 1992). Secretions may also form a foam plug setween the soil surface and oothecae providing a possible oute for emerging nymphs to follow to the soil surface luring eclosion (Ewer, 1977).

Fax: +4116321148

E-mail: shah@micro.biol.ethz.ch
Egg pods are found at different times during the life cycle of a particular grasshopper or locust species (Chapman, 1961; Fishpool \& Popov, 1984; Mestre, 1988). In tropical regions with a marked rainy or monsoon season, species with adult diapause oviposit during the early part of the monsoon season and survive the dry season as immature adults, while those with egg diapause oviposit at the end of the monsoon season and overwinter in the egg stage. Continually reproducing species survive the dry season as adults but can undergo small-scale breeding if habitat conditions become favourable. Most economically important grasshopper species in Africa are univoltine and have an egg diapause stage.

Greathead (1963) provided an extensive catalogue of the natural enemies affecting embryonic and post-embryonic 
orthopteran stages. In the Afrotropical region, 19 species of egg parasitoids were recorded of which 17 were Scelio spp. (Hymenoptera: Scelionidae). From the 83 species of egg predators, 23 were beeflies (Diptera: Bombyliidae) and 14 were blister beetles (Coleoptera: Meloidae). The oothecal stage is considered to be especially vulnerable to attack by natural enemies since egg pods remain in the soil for one to seven months.

The present work forms part of a larger study being undertaken in northern Benin which involves evaluating the impact of natural enemies affecting grasshopper egg pods, determining if seasonal control measures are necessary by assessing egg pod densities and investigating whether mechanical destruction of egg pods during the dry season by farmers may cause long-term reductions in grasshopper numbers.

Between 1992 and 1995, surveys were carried out in northern Benin to: (i) identify possible oviposition sites of agriculturally important egg diapause grasshopper species; (ii) ascertain the effects of natural enemies on nymphal emergence; and (iii) to assess differences in natural enemy levels between seasons, grasshopper species and oviposition sites. Northern Benin is in a high rainfall zone $(800-1000 \mathrm{~mm})$ and the monsoon or rainy season occurs between April and October. Important rain-fed crops are sorghum, millet, maize, cotton, groundnuts and rice, while irrigated tomatoes, onions and potatoes are grown during the early part of the dry season.

\section{Materials and methods}

\section{Field collection of egg pods}

Surveys were based in the districts of Malanville $\left(11^{\circ} 40^{\circ} \mathrm{N}, 30^{\circ} 30^{\prime} \mathrm{E}\right)$, Karimama $\left(12^{\circ} 03^{\prime} \mathrm{N}, 3^{\circ} 11^{\prime} \mathrm{E}\right)$ and Madekali $\left(11^{\circ} 41^{\prime} \mathrm{N}, 3^{\circ} 33^{\prime} \mathrm{E}\right)$. All three districts lie on the southern shores of the Niger and Sadoré Rivers. Surveys were carried out between May and June each year and were timed to coincide with the start of the monsoon season, so the clay-textured soils were sufficiently moistened to allow egg pods to be lifted with mechanical implements but before widespread nymphal hatching had taken place. Since egg pods were laid at the end of the previous monsoon season, surveys in 1992-95 reflected oviposition activities in 1991-94 respectively.

Several egg diapause grasshopper species were known to oviposit preferentially under shrubs or trees (Popov et al., 1990), so searches for egg pods were primarily carried out under shrubs of the legume Piliostigma (=Bauhinia) thonningi. This plant was chosen because it was an easily recognizable perennial, forming extensive stands of $1-5 \mathrm{~m}$ in height at the margins of cultivations or occurring in small groups within cultivated areas. Piliostigma is found in secondary forests throughout the subhumid zones of Africa with more than $700 \mathrm{~mm}$ annual precipitation (von Maydell, 1990).

Before searches could be started, the lower branches of each shrub were excavated using machetes and the soil litter was cleared with rakes. The soil was then carefully scraped away with short-handled hoes to expose any egg pods which may have been present at a depth of $20-120 \mathrm{~mm}$. Egg pods were lifted using trowels or pen knives and placed in labelled plastic containers before transportation to the field laboratory at Malanville. The soil under each shrub was searched in a radial manner and searches usually extended to 1-3 $\mathrm{m}$ away from the main trunk. Five to twenty Piliostigma shrubs were searched in four study sites in each of the three districts for every year of the survey work.

In 1993 and 1995, clumps of the perennial grass Vetiveria nigritana were investigated as possible oviposition sites initially because of suggestions made by farmers assisting in surveys. The height of desiccated Vetiveria clumps varied from $0.2-0.5 \mathrm{~m}$ during the dry season and between $1.0-2.5 \mathrm{~m}$ in the monsoon season. Radial searches extended to between $0.3-0.8 \mathrm{~m}$ from the centre of each clump. Vetiveria is present throughout west Africa especially in the flood plains of the Niger delta (Anon., 1993). In northern Benin, its leaves are used to make traditional thatching and enclosures. As further comparisons in 1993 and 1995, searches were also made in fields of sorghum, Sorghum bicolor, harvested during the previous rainy season, with egg pod samples being taken in visualized $1 \mathrm{~m}^{2}$ quadrats centred around desiccated stalks. At each study site, 15-30 Vetiveria and Sorghum samples were taken.

For Piliostigma and Vetiveria, the radius of search ( $\mathrm{r}$ ) was measured using a $30 \mathrm{~m}$ tape and egg pod densities were calculated from the circular areas searched. Generally, study sites contained a mixture of the three oviposition sites and covered $1-5$ ha in area.

Rainfall data for Malanville was provided by the Centre d'Action Regionale pour le Developpment Rural (CARDER) for Borgou Province.

\section{Laboratory incubations}

Preliminary species identifications of collected egg pods were made using descriptions given by Chapman (1961), Chapman \& Robertson (1958) and Popov et al. (1990). Egg pods were categorized as either being viable (nymphal eclosion from undamaged and unattacked egg pods), non-viable (failure to hatch due to inherent inviability and/or mechanical damage to egg pods during excavation), decayed (oviposited in excessively damp soil), dehydrated (oviposited in excessively dry soil or subjected to excessive desiccation during the dry season), predated (by meloids or other predators) or parasitized by Scelio spp. Meloid predation was confirmed by the presence of larvae or pupae within egg pods or by characteristic holes in egg pod walls signifying attack (Popov et al., 1990).

In 1992, egg pods were incubated in plastic boxes with moistened tissue paper to ascertain the identity of each grasshopper species. This was later discontinued and egg pods collected from 1993 onwards were incubated individually in glass tubes covered with muslin gauze and containing moistened sandy soil. Egg pods were checked every one or two days for the emergence of grasshopper nymphs, predators and/or parasitoids. Emerged nymphs were counted and transferred to large ventilated wooden cages while natural enemies were killed and placed in an insect collection for later taxonomic identification.

\section{Data analysis}

Summary tables were constructed detailing the percentages of viable and non-viable egg pods as well as egg pods classed as decayed, dehydrated or from which natural enemies were identified. 
For the dominant grasshopper species, differences in eclosion success between undamaged, predated and parasitized egg pods were assessed using regression analysis specifying Poisson errors under the Generalized Linear Models procedure (SAS Institute Inc., 1990). Eclosion data were transformed using $\log _{10}(x+1)$, where $x=$ numbers of nymphs emerging over a 30 day incubation period. To determine if the percentages of eggs parasitized per egg pod differed between parasitoid species or for host species, one-way analyses of variance (ANOVAs) were conducted. Percentage data were arc sine transformed prior to analysis.

Mixed model nested factorial ANOVAs (SAS Institute Inc., 1990) were performed for: (i) data obtained from Piliostigma between 1992-1995 to determine if there were any differences in meloid predation, scelionid parasitism or egg pod density between the dominant grasshopper species or survey years; and (ii) data obtained from Piliostigma, Vetiveria and Sorghum in 1993 and 1995 to detect any differences in meloid predation, scelionid parasitism or egg pod density between the three oviposition sites or dominant grasshopper species. Replication was provided by data from four survey sites studied in each of three districts for each of the survey years. Relevant higher order interactions were specified in all cases. Data for meloid predation were transformed using arc sine (range $0-100 \%)$ and a squareroot $(x+0.5)$ transformation was used for percentage parasitism (range $0-30 \%$ ) following guidelines given by Gomez \& Gomez (1984), while egg pod densities were transformed using $\log _{10}(x+1)$ to normalize error variances.

\section{Results}

Rainfall in the Malanville area has an unimodal pattern with the peak generally in August or September. Surveys were conducted in late May or early June after $\mathcal{c} .150-200 \mathrm{~mm}$ had been recorded.

A total of $4545 \mathrm{egg}$ pods was collected from the three oviposition sites in four years, $86 \%$ of egg pods were identified to species or subfamily level while $14 \%$ remained unidentified (table 1). Ten grasshopper species were recorded from incubations, but the four most commonly encountered species were Hieroglyphus daganensis Krauss, Cataloipus fuscocoeruleipes Sjöstedt, Kraussaria angulifera (Krauss) and Tylotropidius gracilipes Brancsik (Orthoptera: Acrididae) which comprised $58 \%, 18 \%, 13 \%$ and $3.9 \%$ respectively of all identified egg pods. Of the 651 unidentified egg pods, $37 \%$ and $40 \%$ were from the 1992 and 1995 surveys respectively. In 1992, egg pods were incubated on damp tissue paper rather than in moistened sand and many could not be identified because the rapid growth of saprophytic fungi prevented nymphal eclosion. Field collections in 1995 were much lower than previous years and a large number of egg pods could not be identified because they failed to hatch during incubation. During the 1995 survey, $51 \%$ of $H$. daganensis egg pods were classed as dehydrated and $58 \%$ of $C$. fuscocoeruleipes were rotten (table 1).

Egg pods of C. fuscocoeruleipes were easily damaged during excavation. For example, in 1993 a total of $153 \mathrm{egg}$ pods were collected but only $28(18 \%)$ could be categorized as truly undamaged specimens without any signs of rupture to foam plugs or egg pod walls and where at least one nymph emerged.

\section{Predation}

Scarabeid and tenebrionid larvae were present in soil litter but were not thought to be specific predators of egg pods and none were found within egg pods. Bombyliid larvae were not found to cause high levels of predation and three adults emerged from 19 larvae incubated between 1992 and 1995 (table 2). One bombyliid larva was found near unidentified egg pods in 1995 but the adult failed to emerge.

A total of 307 late instar meloid larvae and pupae were collected mostly from within egg pods but only ten individuals belonging to eight species emerged (table 2 ). The highest numbers were collected in 1994 when 210 larvae or pupae were found while 12 were collected in 1992, 85 in 1993 and none in 1995. Infection of meloid larvae by an entomopathogen was suspected in 1992 and 1993 because several were found which were extremely desiccated or mummified with a pink body colour. The discovery of a single larva in 1993 with these symptoms and also bearing synemmata was confirmed as being caused by the fungus Cordyceps sp. (H.C. Evans, personal communication). Percentage infection of meloids by Cordyceps sp. was estimated at $1.2 \%$ and $31 \%$ in 1993 and 1994 respectively. Four unidentified scarabeid larvae were also found infected by Cordyceps sp. in 1994.

\section{Parasitism}

Parasitoids were obtained from $66 \mathrm{egg}$ pods of $H$ daganensis, $C$. fuscocoeruleipes, $K$. angulifera, T. gracilipes and Zacompsa festa Uvarov (Orthoptera: Acrididae). Scelio africanus Risbec (Hymenoptera: Scelionidae) was found in 20 egg pods, S. mauritanicus Risbec in 41 egg pods and Scelio sp. (possibly S. pulchripennis Brues) in five egg pods from all five host species. Scelio africanus and S. mauritanicus were not considered to be host specific but Scelio sp. was only reared from Z. festa in 1994. No parasitoids were recorded from surveys performed in 1995.

Scelio spp. parasitized a relatively small number of eggs within grasshopper egg pods. Excluding the 1992 data, where different incubation procedures were used, $S$. mauritanicus parasitized $14 \%$ eggs per egg pod ( $n=36 \mathrm{egg}$ pods, range $=1.7-51 \%$, all grasshopper species), S. africanus parasitized $15 \%$ of eggs $(n=13$, range $=1.4-72 \%)$ but Scelio sp. parasitized $57 \%$ eggs ( $n=5$, range $=5.9-100 \%$ ). This was significantly greater than $S$. mauritanicus or $S$. africanus $\left(\mathrm{F}_{2,48}=5.08, P<0.01\right)$. In 1994, sex ratios of parasitoids emerging from parasitized egg pods of $H$. daganensis were recorded. A male:female ratio of 1.0:2.1 was estimated for $S$. mauritanicus from 28 egg pods and 137 parasitoids, while a ratio of 1.0:3.0 was found for S. africanus from two egg pods and eight individuals ( $G$. Goergen, personal communication).

\section{Effects of natural enemies on nymphal eclosion}

Only eclosion data obtained in 1993 and 1994 were used since unsuitable incubation procedures were employed in 1992 and just two undamaged egg pods were found during the 1995 survey. The lowest numbers of nymphs emerging from undamaged or unattacked egg pods were recorded from $T$. gracilipes (table 3 ).

Predation significantly reduced nymphal eclosion for all of the four dominant grasshopper species. For parasitism, 
Table 1. Viability and mortality of grasshopper egg pods collected from the legume Piliostigma thonningi, the perennial Vetiveria nigritana and from Sorghum bicolor, 1992-1995.

\begin{tabular}{cccc}
\hline Oviposition site and year & $\mathrm{n}$ & \multicolumn{2}{c}{ Percent of egg pods in each category } \\
\cline { 3 - 4 } & $\begin{array}{c}\text { Attack by non- } \\
\text { meloid predators }\end{array}$ & Decayed & Dehydrated \\
\hline Piliostigma & & Non-viable & Viable \\
\hline
\end{tabular}

\section{2}

Cataloipus fuscocoeruleipes

Hieroglyphus daganensis

Kraussaria angulifera

Pyrgomorpha cognata species complex

Tylotropidius gracilipes

Catantopinae

unidentified

Total

197
136
22
1
83
5
238
682

3.1
3.0
9.1
0
3.6
0
15

$\begin{array}{cc}1.5 & 2.5 \\ 0.7 & 12 \\ 4.6 & 9.1 \\ 0 & 0 \\ 0 & 0 \\ 0 & 0 \\ 29 & 7.6\end{array}$

74
77
55
100
93
80
0

1993

C. fuscocoeruleipes

H. daganensis

Homoxyrrhepes punctipennis (Walker)

$K$. angulifera

P. cognata

$T$. gracilipes

Zacompsca festo

unidentified

Total

$\begin{array}{rl}232 & 11 \\ 544 & 7.7 \\ 1 & 0 \\ 100 & 0 \\ 1 & 0 \\ 11 & 0 \\ 1 & 0 \\ 85 & 4.7 \\ 975 & \end{array}$

1994

Acorypha glaucopsis (Walker)

C. fuscocoeruleipes

Hieroglyphus daganensis

Homoxyrhepes punctipennis

$K$ angulifera

Orthochtha ventosa (Ramme)

P. cognata

T. gracilipes

Z. festa

Catantopinae

unidentified

Total

975

1995

C. fuscocoeruleipes

Hieroglyphus daganensis

$K$. angulifera

T. gracilipes

unidentified

Total

1993

C. fuscocoeruleipes

$H$. daganensis

Oedaleus nigeriensis Uvarov

unidentified

Total

19
89
21
2
248
379

0
5.9
3.4
0
0
0
0
0
6.3
0
42

8.6
6.6
0
6.0
0
0
0
20

1.7
2.2
0
0
0
0
0
5.9

$\begin{array}{lr}3.0 & 26 \\ 2.0 & 57 \\ 0 & 100 \\ 2.0 & 75 \\ 0 & 0 \\ 9.1 & 73 \\ 0 & 100 \\ 44 & 0\end{array}$

\section{5}

C. fuscocoeruleipes

H. daganensis

unidentified

Total

$\begin{array}{rcclcr}83 & 21 & 0 & 1.2 & 2.4 & 8.4 \\ 202 & 9.4 & 1.5 & 1.5 & 2.5 & 56 \\ 1 & 0 & 0 & 0 & 0 & 100 \\ 6 & 17 & 17 & 0 & 67 & 0 \\ 292 & & & & & \\ & & & & 33 & 0 \\ 3 & 0 & 33 & 33 & 0 & 0 \\ 8 & 0 & 50 & 48 & 40 & 0 \\ 5 & 0 & 20 & & & \end{array}$

Sorghtum

1993

C. fuscocoeruleipes

H. daganensis

K. angulifera

unidentified

Total

$\begin{array}{rr}26 & 27 \\ 32 & 19 \\ 1 & 0 \\ 2 & 100 \\ 61 & \end{array}$

$\begin{array}{rl}27 & 3.9 \\ 19 & 0 \\ 0 & 0 \\ 100 & 0\end{array}$

$$
\begin{aligned}
& 0 \\
& 0.5 \\
& 4.7 \\
& 0 \\
& 1.6 \\
& 0 \\
& 0 \\
& 0 \\
& 0.4 \\
& 0 \\
& 6.7
\end{aligned}
$$

1995

C. fuscocoeruleipes

H. daganensis

$K$. angulifera

unidentified

Total

$\begin{array}{ll}0 & 58 \\ 0 & 25 \\ 0 & 0 \\ 0 & 0 \\ 0.4 & 7.7\end{array}$

$\begin{array}{rcl}11 & 26 & 0 \\ 51 & 7.8 & 2.3 \\ 71 & 4.8 & 0 \\ 0 & 100 & 0 \\ 85 & 2.0 & 0\end{array}$


Table 2. List of natural enemies from grasshopper egg pods collected in northern Benin.

\begin{tabular}{lll}
\hline Natural enemy & \multicolumn{1}{c}{ Grasshopper host } & Year(s) collected \\
\hline Hymenoptera: Scelionidae & Cataloipus fuscocoeruleipes & 1992,1993 \\
Scelio africanus & $\begin{array}{l}\text { Hieroglyphus daganensis } \\
\text { Kraussaria angulifera }\end{array}$ & $1992,1993,1994$ \\
& Tylotropidius gracilipes & 1992,1994 \\
& C. fuscocoeruleipes & 1994 \\
S. mauritanicus & H. daganensis & 1992,1994 \\
& K. angulifera & 1993,1994 \\
& T. gracilipes & 1994 \\
Scelio sp. & Zacompsa festa & 1992 \\
(S. pulchripennis Brues?) & & 1994 \\
Scelio sp. & Catantopinae & \\
Diptera: Bombyliidae & & 1992 \\
Systoechus littoralis & C. fuscocoeruleipes & \\
S. segetus & nr. H. daganensis and Z. festa & 1992 \\
Coleoptera: Meloidae & nr. H. daganensis & 1994 \\
Epicauta sp. & K. angulifera & 1992 \\
Mylabris haemorrhon King & nr. egg pods & 1994 \\
M. sp. nr. bifasciata De Geer & C. fuscocoeruleipes & 1993 \\
M. sp. nr. holosericia King & C. fuscocoeruleipes & 1993 \\
Mylabris sp. & H. daganensis & 1994 \\
Psalydolytta fusca Olivier & H. daganensis & 1994 \\
P. remedelli Borchmann & C. fuscocoeruleipes \\
P. vesta Dufour & C. fuscocoeruleipes & 1994 \\
Ascomycotina: Pyrenomycetes & H. daganensis & 1993 \\
Cordyceps sp. & C. fuscocoeruleipes & 1993 \\
\hline & meloid larvae & 1993 \\
& & 1993 \\
& & 1993,1994 \\
\hline
\end{tabular}

significant differences in eclosion occurred only for $H$. daganensis (table 4).

\section{Comparison of grasshopper species recovered from Piliostigma 1992-1995}

Egg pod density was significantly higher in 1994 for $H$ daganensis, $C$. fuscocoeruleipes, $K$. angulifera and $T$. gracilipes and lowest in $1995\left(F_{3,132}=7.13, P<0.01\right)$ (fig. 1). Densities of $H$. daganensis were significantly greater compared to the other three grasshopper species $\left(\mathrm{F}_{3,132}=33.20, P<0.0001\right)$. The highest levels of meloid predation were recorded in 1994 $\left(\mathrm{F}_{3,132}=13.88, P<0.0001\right)$ and predation was significantly greater for $C$. fuscocoeruleipes $\left(\mathrm{F}_{3.132}=13.93, P<0.0001\right)$ Scelionid parasitism was highest in 1992 and lowest in 1995 $\left(\mathrm{F}_{3,132}=3.11, P<0.05\right)$. Parasitism was significantly higher for $H$. daganensis and $C$. fuscocoeruleipes compared to K. angulifera and T. gracilipes $\left(\mathrm{F}_{3.132}=2.74, P<0.05\right)$ (fig. 1 ).

\section{Comparison of oviposition sites in 1993 and 1995}

Hieroglyphus daganensis and C. fuscocoeruleipes were the two grasshopper species analysed because only two egg pods of $K$. angulifera and none of $T$. gracilipes were found from Vetiveria or Sorghum during the period when comparative surveys were performed.

The lowest egg pod densities were recorded from Sorghum $\left(\mathrm{F}_{2,42}=13.12, P<0.001\right)$ but there were no differences in meloid predation $\left(\mathrm{F}_{2,92}=1.56, P>0.05\right)$ or parasitism $\left(\mathrm{F}_{2,92}=2.37, P>0.05\right)$ between the three oviposition sites despite parasitism not being recorded from Sorghum. Egg pod density, meloid predation and scelionid parasitism were all higher from collections performed in 1993 compared to $1995\left(\mathrm{~F}_{1,92}=18.59, \quad P<0.01 ; \quad \mathrm{F}_{1,92}=26.34, \quad P<0.001 ; \quad\right.$ and $F_{1,92}=11.15, P<0.01$ respectively) (fig. 2 ).

\section{Discussion}

Prior to these surveys, it had not been reported whether $H$. daganensis, $C$. fuscocoeruleipes or $T$. gracilipes oviposited under Piliostigma shrubs or Vetiveria grass clumps in west Africa. The initial aim was to study egg pods of $K$. angulifera which was known to strongly prefer many species of shrubs and trees for oviposition (Bindra \& Amatobi, 1981; COPR, 1982).

Other orthopteran species also have specific oviposition requirements. Oedaleus senegalensis (Krauss) (Orthoptera: Acrididae) is an important cereal pest in west Africa, preferring to lay egg pods in uncultivated areas but in cultivated fields females will oviposit in plough ridges rather than furrows (Amatobi, 1985; Popov, 1980). In South Africa, egg laying by the African migratory locust, Locusta migratoria migratorioides (Reiche \& Fairmaire) (Orthoptera: Acrididae), was mainly concentrated along crop interrows in maize and within clearings in wheat crops (Price, 1991).

Aggregation of egg pods between shrubs of Piliostigma or clumps of Vetiveria was observed but not quantified statistically. For example, in 1994, 231 egg pods were collected from under a single Piliostigma shrub while only 12-20 egg pods were found under shrubs within a $20 \mathrm{~m}$ radius. This aggregation was likely to have resulted from oviposition by females in areas with optimal microclimatic features of soil moisture and compaction, the possible use of oviposition pheromones, as well as the effects of non-reproductive behaviour including social aggregation (Clark, 1948; 
Table 3. Nymphal numbers recorded from undamaged grasshopper egg pods and egg pods attacked by meloid predators or scelionid parasitoids.

\begin{tabular}{|c|c|c|c|c|c|c|c|c|}
\hline \multirow[t]{3}{*}{ Species } & \multirow[t]{3}{*}{ Year } & \multicolumn{7}{|c|}{ Egg pods } \\
\hline & & \multicolumn{3}{|c|}{ Undamaged $^{a}$} & \multicolumn{2}{|c|}{ Meloid predation } & \multicolumn{2}{|c|}{ Scelionid parasitism } \\
\hline & & $\mathrm{n}$ & $\begin{array}{l}\text { No. nymphs } \\
\text { pod }^{-1}\end{array}$ & $\begin{array}{l}\text { Emergence } \\
\text { period (days) }\end{array}$ & $\mathrm{n}$ & $\begin{array}{l}\text { No. nymphs } \\
\text { pod }^{-1}\end{array}$ & $\mathrm{n}$ & $\begin{array}{l}\text { No. nymphs } \\
\text { pod }^{-1}\end{array}$ \\
\hline \multirow[t]{3}{*}{ Hieroglyphus daganensis } & 1993 & 185 & $\begin{array}{l}53 \\
(1.6)\end{array}$ & $\begin{array}{c}6.5 \\
(0.6)\end{array}$ & 130 & $\begin{array}{l}16 \\
(2.3)\end{array}$ & 9 & $\begin{array}{c}51 \\
(10)\end{array}$ \\
\hline & 1994 & 338 & $\begin{array}{l}42 \\
(1.0)\end{array}$ & $\begin{array}{c}9.6 \\
(0.7)\end{array}$ & 337 & $\begin{array}{l}16 \\
(1.3)\end{array}$ & 30 & $\begin{array}{l}30 \\
(3.0)\end{array}$ \\
\hline & 1995 & 2 & $\begin{array}{l}12 \\
(1.5)\end{array}$ & $\begin{array}{l}1.0 \\
(0)\end{array}$ & 15 & $\begin{array}{c}5.3 \\
(3.0)\end{array}$ & 0 & - \\
\hline \multirow[t]{3}{*}{ Cataloipus fuscocoeruleipes } & 1993 & 28 & $\begin{array}{l}76 \\
(6.6)\end{array}$ & $\begin{array}{l}17 \\
(2.5)\end{array}$ & 110 & $\begin{array}{c}4.2 \\
(1.5)\end{array}$ & 6 & $\begin{array}{c}54 \\
(12.7)\end{array}$ \\
\hline & 1994 & 14 & $\begin{array}{l}52 \\
(8.5)\end{array}$ & $\begin{array}{c}8.6 \\
(3.8)\end{array}$ & 111 & $\begin{array}{c}3.6 \\
(1.2)\end{array}$ & 1 & 12 \\
\hline & 1995 & 0 & - & - & 1 & $\begin{array}{l}0.0 \\
(-)\end{array}$ & 0 & - \\
\hline \multirow[t]{3}{*}{ Kraussaria angulifera } & 1993 & 62 & $\begin{array}{l}66 \\
(3.2)\end{array}$ & $\begin{array}{c}9.5 \\
(1.0)\end{array}$ & 17 & $\begin{array}{l}50 \\
(1.5)\end{array}$ & 0 & - \\
\hline & 1994 & 50 & $\begin{array}{l}67 \\
(4.0)\end{array}$ & $\begin{array}{l}14 \\
(1.9)\end{array}$ & 93 & $\begin{array}{l}20 \\
(2.5)\end{array}$ & 2 & $\begin{array}{l}53 \\
(4.5)\end{array}$ \\
\hline & 1995 & 0 & - & - & 7 & $\begin{array}{c}1.7 \\
(1.9)\end{array}$ & 0 & - \\
\hline \multirow[t]{3}{*}{ Tylotropidius gracilipes } & 1993 & 6 & $\begin{array}{l}24 \\
(4.8)\end{array}$ & $\begin{array}{l}1.0 \\
(-)\end{array}$ & 3 & $\begin{array}{l}24 \\
(1.7)\end{array}$ & 0 & - \\
\hline & 1994 & 19 & $\begin{array}{l}27 \\
(2.8)\end{array}$ & $\begin{array}{c}4.3 \\
(1.2)\end{array}$ & 7 & $\begin{array}{l}15 \\
(4.7)\end{array}$ & 1 & $\begin{array}{c}5.0 \\
(-)\end{array}$ \\
\hline & 1995 & 0 & - & - & 0 & - & 0 & - \\
\hline
\end{tabular}

Standard errors of means in parentheses; aexcluding egg pods injured during excavation.

Popov, 1959; Price, 1991). Clumping within rather than between oviposition sites has been noted by Fisher (1992) in southwest Montana. Higher numbers of egg pods of Aulocara elliotti (Thomas) (Orthoptera: Acrididae) were found on the southern sides of clumps of crested wheatgrass which also had the warmest soil temperatures.
Egg pods of C. fuscocoeruleipes were easily broken during excavation from the soil because they were relatively long and slender $(60-100 \mathrm{~mm}$ length, $7-10 \mathrm{~mm}$ radius) compared to $H$. daganensis ( $30-50 \mathrm{~mm}$ length, $7-12 \mathrm{~mm}$ radius), $K$. angulifera (50-80 $\mathrm{mm}$ length, $10-13 \mathrm{~mm}$ radius) or $T$. gracilipes (35-50 $\mathrm{mm}$ length, 5-8 $\mathrm{mm}$ radius). Additionally, egg pods

Table 4. Summarized results of Poisson regression of the influence of attack by predators or parasitoids on nymphal eclosion.

\begin{tabular}{|c|c|c|c|c|c|}
\hline \multirow[t]{2}{*}{ Species } & \multirow[t]{2}{*}{ Source } & \multicolumn{2}{|c|}{ Predation } & \multicolumn{2}{|c|}{ Parasitism } \\
\hline & & $x^{2}$ & $\begin{array}{l}\text { Parameter } \\
\text { estimate }\end{array}$ & $z^{2}$ & $\begin{array}{c}\text { Parameter } \\
\text { estimate }\end{array}$ \\
\hline \multirow[t]{4}{*}{ Hieroglyphus daganensis } & Intercept & & $2.8(0.1)$ & & $3.4(0.1)$ \\
\hline & Year & 0.8 & $-0.4(0.1)$ & $19^{* * *}$ & $0.5(0.2)$ \\
\hline & Attack & $317^{* * *}$ & $1.0(0.1)$ & $3.9^{*}$ & $0.3(0.1)$ \\
\hline & Year*Attack & $19^{* * *}$ & $0.6(0.1)$ & 2.6 & $0.2(0.2)$ \\
\hline \multirow[t]{4}{*}{ Cataloipus fuscocoeruleipes } & Intercept & & $1.3(0.4)$ & & $2.5(1.2)$ \\
\hline & Year & 0.0 & $-0.3(0.5)$ & 2.6 & $1.6(1.2)$ \\
\hline & Attack & $116^{* * *}$ & $2.7(0.4)$ & 2.0 & $1.5(1.2)$ \\
\hline & Year*Attack & 1.6 & $0.7(0.6)$ & 1.0 & $-1.2(1.2)$ \\
\hline \multirow{4}{*}{ Kraussaria angulifera } & Intercept & & $3.0(0.1)$ & & $4.0(0.3)$ \\
\hline & Year & $23^{* * *}$ & $1.0(0.2)$ & 0.1 & $0.0(0.1)$ \\
\hline & Attack & $48^{* * *}$ & $1.2(0.1)$ & 0.6 & $0.2(0.3)$ \\
\hline & Year*Attack & $25^{* * *}$ & $-1.0(0.2)$ & - & - \\
\hline \multirow[t]{4}{*}{ Tylotropidius gracilipes } & Intercept & & $2.8(0.3)$ & & $1.6(1.1)$ \\
\hline & Year & 0.5 & $-0.3(0.5)$ & 0.3 & $-0.1(0.2)$ \\
\hline & Attack & $4.4^{*}$ & $0.5(0.4)$ & 2.6 & $1.7(1.1)$ \\
\hline & Year*Attack & 0.1 & $0.2(0.5)$ & - & - \\
\hline
\end{tabular}

$\chi^{2}$ values only given for sources of variation and not for intercepts or other parameter estimates; ${ }^{*} P<0.05$ ${ }_{* * *} P<0.001$; $\mathrm{df}$ for sources of variation $=1$; Standard errors for parameter estimates in parentheses. 

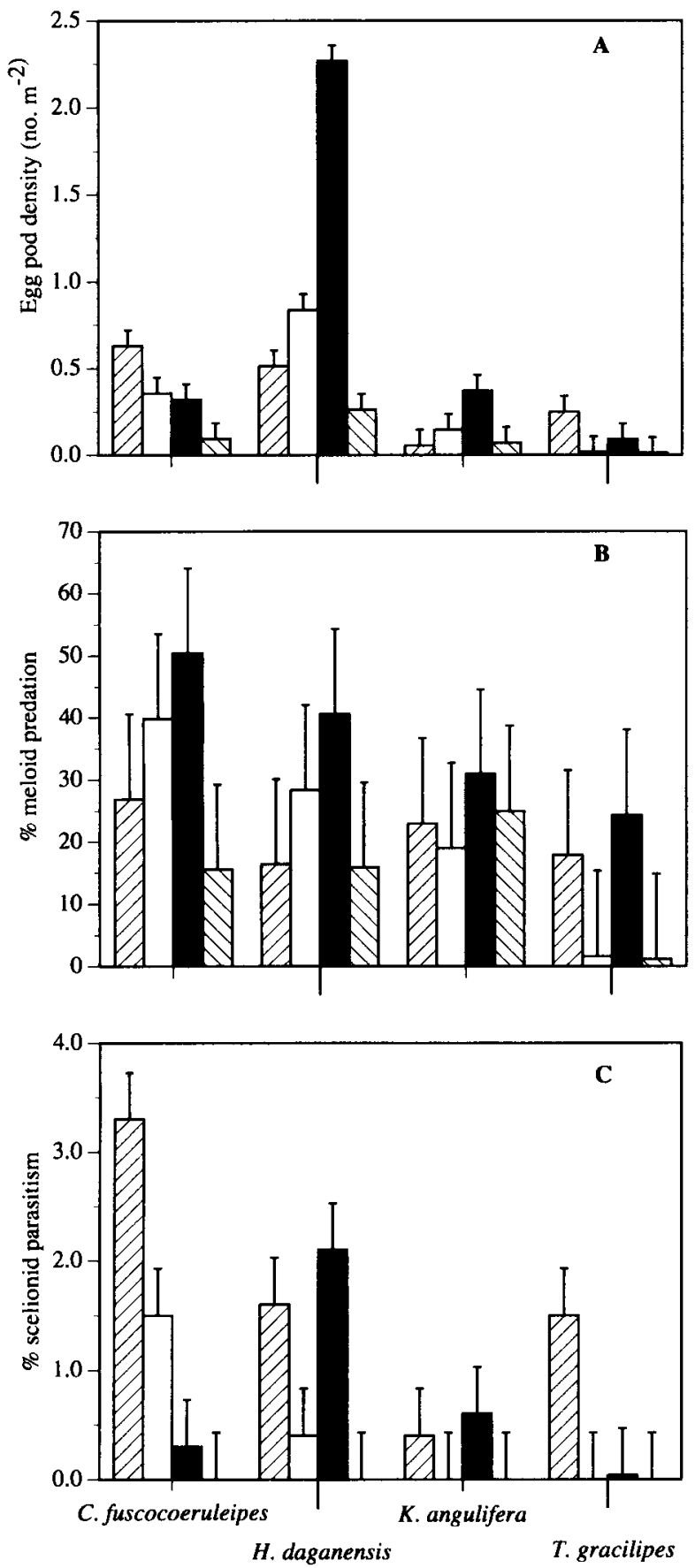

Fig. 1. Mean values of egg pod density (A), meloid predation (B) and scelionid parasitism (C) for the four dominant grasshopper species found under Piliostigma in 1992 (『), $1993(\square), 1994$ ( and $1995(\mathbb{\mathbb { N }})$

of $H$. daganensis and $K$. angulifera formed very hard capsules which were extremely resistant to mechanical penetration.

Meloid predation may have been higher for C. fuscocoeruleipes because egg pods were longer and less resistant to mechanical penetration facilitating the location and entry of oothecae by predatory larvae. Eclosion from undamaged egg
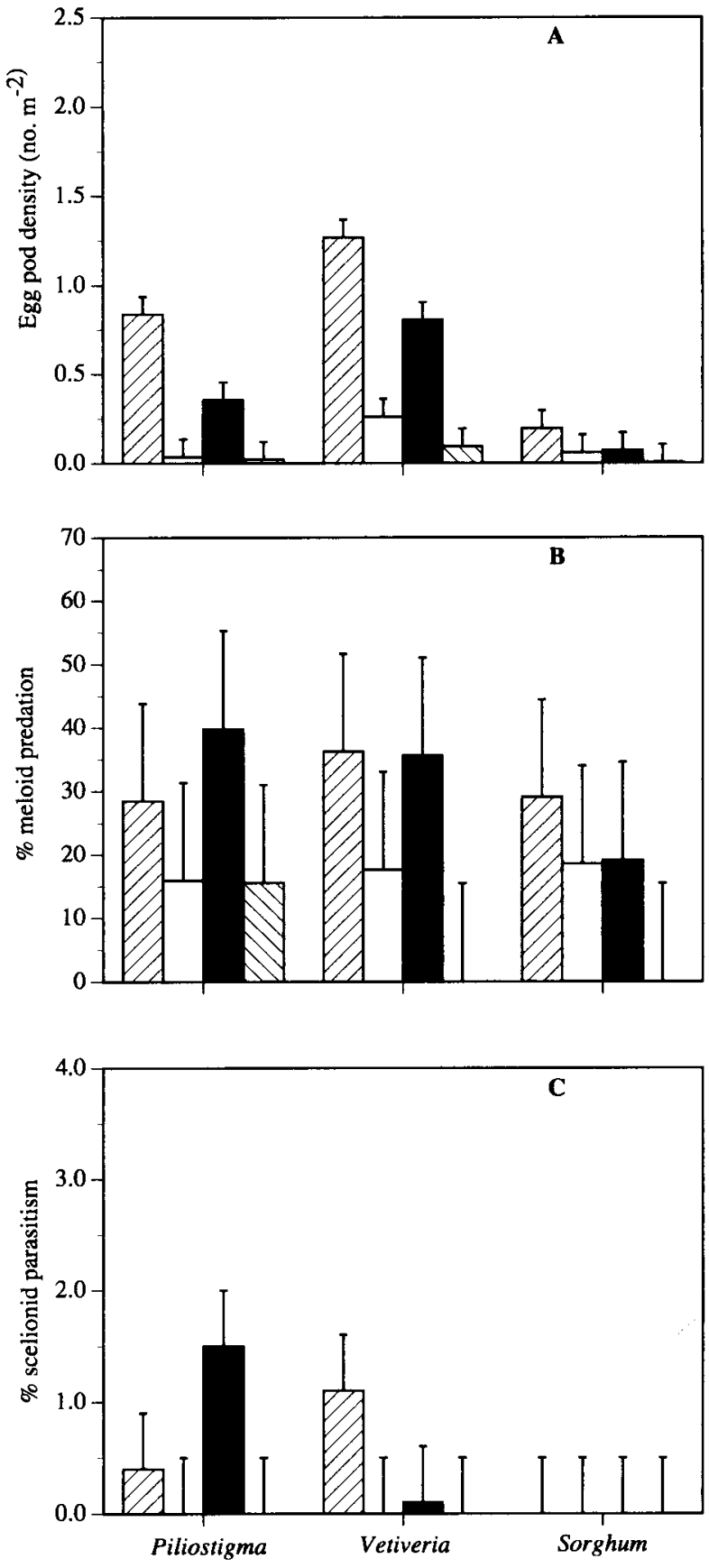

Fig. 2. Comparisons of egg pod density (A), meloid predation (B) and scelionid parasitism (C) between the three oviposition sites for Hieroglyphus daganensis in $1993(\mathbb{B})$ and $1995(\square)$ and for Cataloipus fuscocoeruleipes in $1993(\mathbb{0})$ and $1995(\mathbb{Q})$.

pods of either $H$. daganensis, C. fuscocoeruleipes, $K$. angulifera or $T$. gracilipes was significantly greater than from egg pods attacked by meloids. This implies that viability is reduced even when egg pods do not contain any meloid larvae but show signs of meloid attack signified by the presence of one or more pits through the egg pod walls. In northwest Mali, 
Psalydolytta pilipes Maklin and P. vestita Dufour (Coleoptera: Meloidae) were reared from egg pods of several grasshopper species. The only exception was $O$. senegalensis whose smaller, more slender egg pods may have restricted larval development (Grunshaw et al., 1994). Psalydolytta fusca Olivier (Coleoptera: Meloidae) has been reared from $C$. fuscocoeruleipes egg pods in Gambia (Selander \& Laurense, 1987).

The present report of Cordyceps sp. from meloid larvae was interesting as the fungal genus is most common in humid, tropical forests (Samson et al, 1988) but scarce in areas of depleted forests and agricultural land which characterized our surveys.

All Systoechus spp. are predators of grasshopper and locust egg pods (Greathead, 1958). Systoechus littoralis Bowden and S. segetus Bowden (Diptera: Bombyliidae) have previously been identified from Ghana (D.J. Greathead, personal communication).

Rearings of $S$. africanus and $S$. mauriticanus from $H$. daganensis, C. fuscocoeruleipes, $K$. angulifera and $T$. gracilipes appear to constitute new host recordings based on previous literature (Nixon, 1958; Popov et al., 1990; Siddiqui et al., 1986). Scelio spp. in northern Benin are likely to be univoltine since their grasshopper hosts have one generation per year. Voltinism in Scelio has been found to alter with changes in latitude and host biology (Baker et al., 1985). Parasitism by Scelio spp. involves the use of an anatomically and mechanically unique telescopic ovipositor system into the upper portions of orthopteran egg pods (Field \& Austin, 1994). Popov (1959) argued that puparia discarded by adults of $S$. sudanensis Ferriere from parasitized eggs of L. m. migratorioides caused blockages preventing first instar nymphs from exiting egg pods. Evidence from the present study indicates that parasitism by Scelio spp. significantly reduced the numbers of nymphs emerging from egg pods of $H$. daganensis, where a larger sample size was available for comparison with unparasitized egg pods. For all grasshopper species, relatively small numbers of eggs were parasitized within individual egg pods.

The low levels of egg pod and egg parasitism recorded in the present study suggest that Scelio spp. do not have a major role in regulating grasshopper numbers. Meloid predators appear to be the dominant obligate arthropod natural enemies of egg pods and may cause some regulation in grasshopper numbers but these predators are also attacked by a fungal entomopathogen so limiting their effectiveness.

Laboratory incubations of grasshopper adults and nymphs collected from two sites in Malanville between 1992 and 1995 indicated regular low level infections of less than $4.0 \%$ caused by the fungal entomopathogen Metarhizium flavoviride but endoparasitoids were recorded only once during the four year study (Shah et al., 1994, 1998). Hence, natural enemies reared from laboratory incubated hosts appear to be most active against oothecal rather than post-embryonic stages of grasshoppers but no attempts have been made so far to quantify losses due to predation of grasshopper nymphs or adults in northern Benin

Abiotic factors have an important role in affecting the survival of orthopteran egg pods. For example, soil temperatures and rainfall have been shown to influence oothecal viability of O. senegalensis in Mali (Colvin, 1997). In the current study, very low numbers of egg pods collected in 1995 may have resulted from widespread flooding of oviposition sites during the previous season. Further investigations are required to determine the relationship between egg pod survival and abiotic conditions in northern Benin. A control strategy could then be developed combining biotic and abiotic factors to predict when mechanical destruction of egg pods by farmers should be undertaken to prevent crop damage.

\section{Acknowledgements}

We thank M. Bio Beri of CARDER-Borgou, farmers and extension agents in northern Benin and technicians at the International Institute for Tropical Agriculture (IITA) Cotonou for their enthusiastic assistance. Comments and advice on conducting surveys by G.B. Popov and D.J. Greathead were greatly appreciated. Taxonomic identifications of predators and parasitoids were made by R.B. Booth, A. Polazsek (International Institute of Entomology, IIE), D.J. Greathead (International Institute of Biological Control, IIBC Silwood Park), G. Goergen and H. Davies (IITA Cotonou). Statistical advice was given by $\mathrm{S}$. Nokoe (IITA Ibadan), F. Schulthess (IITA Cotonou), H. Rohr and M. Wolbers (Mathematik-Seminar für Statistik, ETH Zürich). Financial support was provided by the Canadian International Development Agency (CIDA), the Overseas Development Agency of the UK (ODA), the Directorate General for Development Cooperation of the Netherlands (DGIS) and Swiss Development Cooperation (SDC).

\section{References}

Amatobi, C.I. (1985) Oviposition preference and the influence of cultivation on egg hatching in Oedaleus senegalensis (Orthoptera: Acrididae). Samaru Journal of Agricultural Research 3, 81-85.

Anon. (1993) Vetiver grass: a thin green line against erosion. $171 \mathrm{pp}$. National Research Council, Washington DC, National Academy Press.

Baker, G.L., Pigott, R. \& Galloway, I. (1985) The phenology of Scelio spp. (Hymenoptera: Scelionidae), parasites of acridid eggs (Orthoptera: Acrididae) in south east Australia. pp. 268-275 in Chapman, R.B. (Ed.) Proceedings of the 4th Australasian Conference on Grassland Invertebrate Ecology, Lincoln College, University College of Agriculture, Canterbury, New Zealand. Caxton Press, Christchurch, New Zealand.

Bindra, O.S. \& Amatobi, C.I. (1981) Bionomics of Kraussaria angulifera Krauss (Orthoptera: Acrididae) in northern Nigeria. Samaru Journal of Agricultural Research 1, 59-67.

Chapman, R.F. (1961) Egg pods from grasshoppers collected in southern Ghana. Journal of the Entomological Society of South Africa 24, 259-284.

Chapman, R.F. \& Robertson, I.A.D. (1958) The egg pods of some tropical African grasshoppers. Journal of the Entomological Society of South Africa 21, 85-112.

Clark, E.J. (1948) The ecology of British grasshoppers. Transactions of the Royal Entomological Society of London 99, 173-222.

Colvin, J. (1997) Biotic and abiotic factors affecting the population dynamics of the Senegalese grasshopper, Oedaleus senegalensis. pp. 63-67 in Krall, S., Peveling, R. \& Ba Diallo, D. (Eds) New strategies in locust control. Basel, Birkhaüser Verlag. 
COPR (1982) The locust and grasshopper agricultural manual. $560 \mathrm{pp}$. London, Centre for Overseas Pest Research.

Ewer, D.W. (1977) Two functions of the foam plug of acridid egg pods. Acrida 6, 1-18.

Field, S.A. \& Austin, A.D. (1994) Anatomy and mechanics of the telescopic ovipositor system of Scelio Latreille (Hymenoptera: Scelionidae) and related genera. International Journal of Insect Morphology and Embryology 23, 135-158.

Fisher, J.R. (1992) Location of egg pods of Aulocara elliotti (Orthoptera: Acrididae) in a field of crested wheat in Montana. Journal of the Kansas Entomological Society 65, 416-420.

Fishpool, L.D.C. \& Popov, G.B. (1984) The grasshopper faunas of the savannas of Mali, Niger, Benin and Togo. Bulletin de l'Institute Fondamental d'Afrique Noire 43, 275-410.

Gomez, K.A. \& Gomez, A.A. (1984) Statistical procedures in agricultural research. 2nd edn. $680 \mathrm{pp}$. New York, John Wiley and Sons.

Greathead, D.J. (1958) Observations on two species of Systoechus (Diptera: Bombyliidae) preying on the Desert Locust, Schistocerca gregaria (Forskål), in eastern Africa. Entomophaga 1, 5-22.

Greathead, D.J. (1963) A review of the insect enemies of Acridoidea (Orthoptera). Transactions of the Royal Entomological Society of London 114, 437-517.

Greathead, D.J. (1992) Natural enemies of tropical locusts and grasshoppers: their impact and potential as biological control agents. pp. 105-121 in Lomer, C.J. \& Prior, C. (Eds) Biological control of locusts and grasshoppers. Wallingford, Oxon, CAB International.

Grunshaw, J.P., Mariko, S. \& Troare, I. (1994) Field studies on the biology and economic importance of Psalydolytta spp. (Coleoptera: Meloidae: Meloinae) in Mali, West Africa. Bulletin of Entomological Research 84, 493-502.

Mestre, J. (1988) Les acridiens des formations herbeuses d'Afrique de l'Ouest. $330 \mathrm{pp}$. Paris, Ministère de la Coopération et CIRAD/GERDAT

Nixon, G.E.J. (1958) A synopsis of the African species of Scelio Latreille (Hymenoptera: Proctotrupoidea, Scelionidae). Transactions of the Royal Entomological Society of London 110, 303-318.

Popov, G.B. (1959) Ecological studies on oviposition by Locusta migratoria migratorioides (R. \& F.) in its outbreak area in the French Sudan. Locusta 6, 5-63.
Popov, G.B. (1980) Studies on oviposition, egg development and mortality in Oedaleus senegalensis (Krauss), (Orthoptera, Acridoidea) in the Sahel. $48 \mathrm{pp}$. London, Miscellaneous Report No. 53, Centre for Overseas Pest Research.

Popov, G.B., Launois-Luong, M.H. \& van der Weel, J.J. (1990) Les ootheques des criquets $d u$ Sahel. $153 \mathrm{pp}$. Niamey, Collection Acridologie Opérationnelle No. 7. Ministère des Affaires Étrangères des Pays-Bas et CIRAD/PRIFAS (France).

Price, R.E. (1991) Oviposition by the African migratory locust, Locusta migratoria migratorioides, in a crop environment in South Africa. Entomologia Experimentalis et Applicata 61, 169-177.

SAS Institute Inc. (1990) SAS/STAT" user's guide, Version 6, 4th edn. Volume 1, 943 pp., SAS Institute Inc., Cary, North Carolina.

Samson, R.A., Evans, H.C. \& Latgé, J.P. (1988) Atlas of entomopathogenic fungi. $187 \mathrm{pp}$. Berlin, Springer-Verlag

Selander, R.B. \& Laurense, A.A. (1987) On the immature stages of Psalydolytta fusca (Coleoptera: Meloidae). Proceedings of the Entomological Society of Washington 89, 489-499.

Shah, P.A., Godonou, I., Gbongboui, C. \& Lomer, C.J. (1994) Natural levels of fungal infections in grasshoppers in northern Benin. Biocontrol Science and Technology 4, 331-341.

Shah, P.A., Gbongboui, C., Godonou, I., Hossou, A. \& Lomer, C.J. (1998) Natural incidences of Metarhizium flavoviride infections from two grasshopper communities in northern Benin. Biocontrol Science and Technology 8, in press

Siddiqui, R.K., Irshad, M. \& Mohyuddin, A.I. (1986) Scelio spp. as biocontrol agents of acridids. Biocontrol News and Information 7, 69-76.

Uvarov, B.P. (1977) Grasshoppers and locusts, a handbook of general acridology. $481 \mathrm{pp}$. Volume 2. Cambridge University Press.

von Maydell, H.J. (1990) Trees and shrubs of the Sahel: their characteristics and uses. $525 \mathrm{pp}$. Weikersheim, Verlag Josef Margraf.

(Accepted 28 April 1998)

c. CAB INTERNATIONAL, 1998 